\title{
Rafal Pitera
}

University of Rzeszow, Faculty of Economics, Rzeszow, Poland

e-mail: rpitera@ur.edu.pl

ORCID: 0000-0001-9598-1240

\section{VERIFICATION OF SELECTED METHODS OF ASSESSING THE FINANCIAL SITUATION OF A COMPANY}

\section{WERYFIKACJA WYBRANYCH METOD OCENY SYTUACJI FINANSOWEJ PRZEDSIĘBIORSTWA}

\author{
DOI: $10.15611 / \mathrm{pn} .2019 .4 .04$
}

JEL Classification: M400

Summary: The article attempts to evaluate selected diagnostic tools classified as early warning methods. They are usually used to assess the current financial condition of a company, they are also used to predict bankruptcy. The most popular methods were verified, namely discriminant models, logit models and scoring models. Based on the collected financial data of enterprises that in 2010-2016 declared liquidation bankruptcy and their healthy counterparts, the usefulness of individual models was assessed in terms of the reliability of the results obtained. The analysis shows that the scoring model was the most effective in assessing the financial situation. Discrimination models came the second in this respect. Logit models proved to be the least effective. All the models used in the study were characterized by a level of accuracy of forecasts above $50 \%$, which indicates a good result. The conducted study confirms the legitimacy of using such tools. They are also evidence of the continuing popularity of early warning models among people assessing the financial situation in an enterprise.

Keywords: methods of early warning, bankruptcy of enterprises, financial analysis.

Streszczenie: W artykule podjęto próbę oceny wybranych narzędzi diagnostycznych zaliczanych do metod wczesnego ostrzegania. Służą one do oceny bieżącej kondycji finansowej przedsiębiorstwa, są także wykorzystywane do predykcji upadłości. Weryfikacji poddane zostały najpopularniejsze metody, mianowicie modele dyskryminacyjne, logitowe oraz model scoringowy. Na podstawie danych finansowych spółek, które w latach 2010-2016 ogłosiły upadłość likwidacyjną, oraz ich „,zdrowych” odpowiedników dokonano oceny przydatności modeli pod kątem wiarygodności wyników. Najskuteczniejszy w ocenie sytuacji finansowej okazał się model scoringowy. Drugie były modele dyskryminacyjne. Najmniej skuteczne okazały się modele logitowe. Wszystkie modele wykorzystane w badaniu charakteryzowały się poziomem trafności powyżej 50\%, co świadczy o dobrym wyniku. Badanie potwierdza zasadność wykorzystywania tego rodzaju narzędzi. Są także dowodem niesłabnącej popularności modeli wczesnego ostrzegania.

Słowa kluczowe: modele wczesnego ostrzegania, upadłość przedsiębiorstw, analiza finansowa. 


\section{Introduction}

The operation of an enterprise in a market economy carries many risks and uncertainties. One of the basic and most frequently occurring threats is the risk of an individual's bankruptcy due to the existence of various types of barriers and obstacles. In order to be able to function effectively in an economic environment, an enterprise must constantly make many decisions both in its operations and its strategy. One of the areas particularly important for the entire company's operations are decisions made in the financial aspect. This area affects not only the correct operation of the enterprise, and it can also bring many benefits in connection with appropriate and effective management. On the other hand, wrong decisions generate problems for the company. They can also create threats to the future operations of the entity. The area of corporate finance management in the aspect of the assessment and monitoring of a company's situation seems to be one of the most important.

The article attempts to systematize the tools used in assessing the financial situation of an enterprise in terms of effectiveness of results. In order to achieve the assumed goal, some data were collected on 25 bankrupt companies and their 25 healthy counterparts. Companies with a good financial condition were selected as entities similar in terms of their activity, asset structure or size to the bankrupt companies. The data of the companies that declared bankruptcy were taken from the years 2010-2016. An application for declaration of liquidation bankruptcy was filed with the district court against these companies.

The companies included in the research sample came from nine provinces. Based on the collected empirical data, four discriminant models, three logit models and one scoring model were assessed.

\section{Literature review}

In the literature on the subject, a number of publications dealing with issues related to the assessment of the financial situation can be found. The subject literature presents numerous attempts to verify early-warning models. It is worth mentioning some of the most interesting publications that bring very interesting conclusions. One of such is undoubtedly the conclusions obtained from the research carried out by P. Antonowicz who examined 52 discriminatory methods on a sample of $89 \mathrm{com}-$ panies based in the Pomorskie Voivodeship, which in 2003-2004 declared bankruptcy. He counted as their counterparts 119 enterprises ranked in Gazele Biznesu 2004 [Antonowicz 2010, p. 19]. R. Balina gathered data from 60 entities - 30 bankrupts and 30 healthy counterparts. All the entities were public limited liability companies from the construction sector. Based on the financial data of these entities, he assessed the prognostic reliability of discriminatory models [Balina 2012, pp. 233-234]. A. Kuciński assessed the financial situation of New Connect companies using discriminatory models [Kuciński 2011, pp. 146-163]. M. Hamrol and J. Chodakowski 
conducted a survey based on a sample of 36 companies present on the Warsaw Stock Exchange, which filed for bankruptcy or arrangement proceedings in 2002-2004 [Hamrol, Chodakowski 2008, p. 29]. L. Czapiewski also attempted to evaluate discriminatory models in his study using the financial data of 94 listed companies 48 threatened with bankruptcy in the period 2000-2004, and 46 with a good level of financial condition [Czapiewski 2009, p. 123]. W. Lichota assessed the effectiveness of discriminant models based on a sample of eight enterprises from the Podkarpackie Voivodeship. The companies filed for liquidation bankruptcy in the period 2003-2014 [Lichota 2017, pp. 212-213]. The evaluation of early warning models was also undertaken by G. Gołębiowski and K. Żywno. They investigated the prognosis effectiveness on the basis of financial data from ten companies from the Warsaw Stock Exchange against which an application for bankruptcy was filed [Gołębiowski 2008, p. 36]. J. Kitowski, on the other hand, attempted to assess the credibility of banking methods. He chose for this purpose and made prognostic verification of five methods used by Polish banks in assessing the financial condition of enterprises applying for a loan [Kitowski 2011]. E. Grzegorzewska together with H. Runowski assessed the prognostic effectiveness of discriminatory methods. Based on 51 breeding companies of the Agricultural Property Agency, which operated from 1996 to 2007 operated. From this set, for each surveyed year, they selected 12 endangered enterprises and 12 companies with a good financial condition. In the study they used ten discriminatory models [Grzegorzewska, Runowski 2008, p. 84]. The attempt of the suitability of methods using the linear function of discrimination in assessing the financial condition was carried out by D. Zarzecki. He evaluated 21 companies, with nine of them characterised by poor financial conditions and 12 of them being sound counterparts [Zarzecki 2003, p. 179]. J. Wojnar assessed the effectiveness of ninr discriminatory models on a sample of 50 listed companies, and distinguished three groups: 20 companies with no threats, 10 companies listed on the stock exchange but with difficult financial conditions and threatened with bankruptcy, and companies once listed but with a financial standing that disqualified them from being present on the trading floor [Wojnar 2014, pp. 219-231]. J. Kisielińska together with A. Waszkowski on a sample of e enterprises that declared bankruptcy and their eight healthy counterparts, assessed the effectiveness of logit and discriminatory models [Kisielińska, Waszkowski 2010, pp. 17-31]. A. Czarny, based on financial data from a sample of 26 companies from 2001-2005, verified the effectiveness of early warning models. The enterprises came from the food and beverage production sector [Czarny 2009, pp. 129-130]. G. Gołębiowski and A. Pląsek investigated the effectiveness of discriminatory models based on enterprises from the tourism industry. On the basis of a sample of 30 entities - 18 healthy and 12 sick ones, they examined a total of 17 Polish discriminant models and three foreign ones [Gołębiowski, Pląsek 2018, pp. 9-24]. In the studies of S. Juszczyk, J. Pochopien and R. Balina, 26 Polish discriminant models were analysed. The empirical test was made up of 40 companies from the road transport sector (PKD 49.41z). Of these, 20 companies in 2009 declared 
bankruptcy, and the remaining 20 continued to operate [Juszczyk et al. 2013, pp. 34-40]. It is also worth noting the research carried out by J. Kisielińska who verified the effectiveness of early warning models using financial data from 2009-2012. The data came from a sample of 110 enterprises, half of which were companies that went bankrupt and half that did not. The verification of 11 Polish models of early warning (seven discriminant methods and four logit), as well as the aggregated method created on the basis of the above methods [Kisielińska 2016, pp. 5-17]. Research on the verification of early warning methods was also discussed by authors such as T. Stasiewski [1996], W. Rogowski [1997] and J. Koralun-Bereźnicka [2006].

The research results quoted above has led to several conclusions. First, discriminatory methods are the most popular among models assessing the financial condition of the company. The second in this classification should be logit models. It is rarely possible to find research works in which other types of tools are subject to verification, such as scoring methods, artificial neural networks or traditional index analysis. While assessing the research, one can also see that most authors verify from a few to a dozen or so methods. However, the size of the research sample in most studies is between 10 and 30 entities, it is rarely a sample of 50 or more enterprises.

\section{Description of the methods and the research sample}

The article reviews eight early warning models: four discriminant models, three logit models and one scoring model. Among the discriminatory methods were: the "G" INE PAN model by E. Mączyńska and M. Zawadzki, the J. Gajdka and D. Stos model from 2003, the Poznan model, and the D. Appenzeller and K. Szarzec model. The logit methods chosen for the study are the following: the Hołda model, the Korol model, and the Wędzki model. The scoring method subject to verification is a modification of the point method of bank risk assessment according to the variant of A. Hołda. The above models were evaluated in terms of the effectiveness of financial forecasts based on the financial data of 25 enterprises which between 2010 and 2016 declared liquidation bankruptcy, and their 25 healthy counterparts.

Healthy enterprises were selected in a non-random manner as a selection of enterprises similar in terms of the size of assets, employment and business profile.

The enterprises included in the services, production and construction sectors were selected for the bankruptcy sample. The same number of enterprises from individual sectors was selected for their healthy counterparts. In the bankruptcy group, the average value of assets for trading enterprises was 3,147.374 PLN, manufacturing enterprises 5,025.914 PLN, service enterprises 2,936.157 PLN. The average value of assets for healthy enterprises from the trade sector was 3,944.958 PLN, production 6,754.598 PLN, and service 3,444.596 PLN. Enterprises from both groups were characterized by employing over 50 employees on a full-time basis. The legal form of bankrupt enterprises were 19 limited liability companies and six joint-stock companies. In the sample of healthy enterprises, there were 20 limited liability com- 
panies and five joint-stock companies. Table 1 presents the most important parameters of the companies included in the research sample.

Table 1. Selected parameters of enterprises included in the research sample

\begin{tabular}{|c|c|c|}
\hline Enterprises & Bankrupts & Healthy \\
\hline \multicolumn{3}{|l|}{ Legal form } \\
\hline Limited liability company & 19 & 20 \\
\hline Joint-stock company & 6 & 5 \\
\hline \multicolumn{3}{|l|}{ Number of enterprises } \\
\hline Trading companies & 8 & 8 \\
\hline Production companies & 10 & 10 \\
\hline Service enterprises & 7 & 7 \\
\hline \multicolumn{3}{|l|}{ Average asset value (PLN) } \\
\hline Trading companies & $3,147.374$ & $3,944.958$ \\
\hline Production companies & $5,025.914$ & $6,754.598$ \\
\hline Service enterprises & $2,936.157$ & $3,444.596$ \\
\hline
\end{tabular}

Source: own study.

The article presents the results of the study for the last period - classification according to the effectiveness of forecasts. The characteristics of each method are presented below.

Discrimination model “G” INE PAN by E. Mączyńska and M. Zawadzki:

$Z_{\mathrm{EM}}=9.498 * \mathrm{I} 1+3.566 * \mathrm{I} 2+2.903 * \mathrm{I} 3+0.452 * \mathrm{I} 4-1498$

$\mathrm{I} 1=\mathrm{EBIT} /($ Assets $)$

$\mathrm{I} 2=($ Equity capital $) /($ Assets $)$

$\mathrm{I} 3=($ Net profit + Depreciation $) /($ Liabilities $)$

I4 $=($ Current assets $) /($ Current liabilities $)$

$\mathrm{Z}_{\mathrm{EM}}>0$ good financial condition

$\mathrm{Z}_{\mathrm{EM}}<0$ bankruptcy [Mączyńska 2006];

Discrimination model by J. Gajdka and D. Stos from 2003:

$\mathrm{Z}_{\mathrm{JG}}=-0.0005 * \mathrm{I} 1+2.0552 * \mathrm{I} 2+1.7260 * \mathrm{I} 3+0.1155 * \mathrm{I} 4-0.3342$

I1 $=($ Average annual current liabilities *360)/(Manufacturing cost)

$\mathrm{I} 2=($ Net profit $) /($ Average annual assets $)$

$\mathrm{I} 3=($ Gross profit $) /($ Total sales revenues $)$

I4= Assets / Liabilities

$\mathrm{Z}_{\mathrm{JG}}>0$ good financial condition

$\mathrm{Z}_{\mathrm{JG}}<0$ bankruptcy

$-0.49<=\mathrm{Z}_{\mathrm{JG}}=<0.49$ "area of uncertainty", no indication of the financial situation [Stos, Gajdka 2003]. 


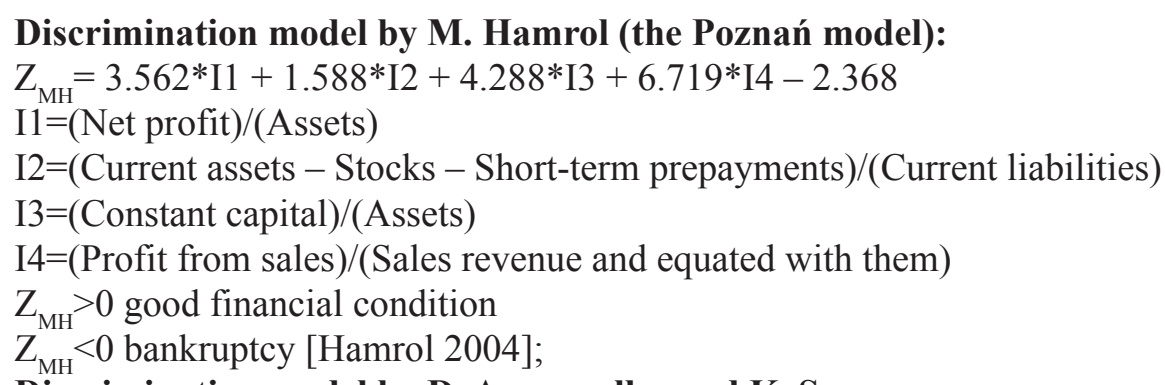

Discrimination model by D. Appenzeller and K. Szarzec:

$\mathrm{Z}_{\mathrm{DA}}=0.819 * \mathrm{I} 1+2.567 * \mathrm{I} 2-0.005 * \mathrm{I} 3+0.0006 * \mathrm{I} 4-0.0095 * \mathrm{I} 5-0.556$

$\mathrm{I} 1=$ Current assets/Current liabilities

I $2=$ EBIT $/$ Total sales revenues

I3=(Average annual stocks * number of days $) /$ Total sales revenues

I4 $=$ Debt rotation + Stock rotation

I5 $=($ Liabilities and provisions for liabilities /EBITDA $) *(12 /$ Fiscal period $)$

$\mathrm{Z}_{\mathrm{DA}}>0$ good financial condition

$\mathrm{Z}_{\mathrm{DA}}<0$ bankruptcy [Appenzeller, Szarzec 2004];

\section{Logit model by A. Hołda:}

$\mathrm{Z}_{\mathrm{AH}}=-0.52+4.50 * \mathrm{I} 1-7.98 * \mathrm{I} 2+0.93 * \mathrm{I} 3+2.31 * \mathrm{I} 4+7.32 * \mathrm{I} 5$

$\mathrm{I} 1=$ Current assets/Current liabilities

I2 $=($ Total liabilities/Assets $) * 100 \%$

$\mathrm{I} 3=$ Total sales revenues/Average annual assets

I4=(Average annual current liabilities/Costs of products, goods and materials sold) $* 360$

I5 $=($ Net profit/Average annual assets $) * 100$

$\mathrm{Z}_{\mathrm{AH}}>0$ good financial condition

$\mathrm{Z}_{\mathrm{AH}}<0$ bankruptcy [Hołda 2001].

Logit model by T. Korol:

$\mathrm{Z}_{\mathrm{TK}}=2.0-10.19 * \mathrm{I} 1-4.58 * \mathrm{I} 2-0.57 * \mathrm{I} 3$

$\mathrm{I} 1=$ Profit from sales/Assets

$\mathrm{I} 2=($ Net profit + Depreciation $) /$ Liabilities

I3 $=$ Operation costs/Current liabilities

$\mathrm{Z}_{\mathrm{TK}}<=0.5$ good financial condition

$\mathrm{Z}_{\text {TK }}>0.5$ bankruptcy.

This is a contractual determination of the limit value, because the author did not specify such a level. The adoption of the value of 0.5 resulted from the fact that the learning sample approximately contained the proportion bankrupt / non-bankrupt $50 \% / 50 \%$, therefore the limit value for the model has been accepted [Korol 2010];

\section{Logit model by D. Wędzki:}

$\mathrm{Z}_{\mathrm{DW}}=-4.0-6.0 * \mathrm{I} 1+9.387 * \mathrm{I} 2-2.088 * \mathrm{I} 3+1.317 * \mathrm{I} 4+0.04 * \mathrm{I} 5-4.217 * \mathrm{I} 6$

I1 $=($ Current assets + Pre-paid accruals)/(Current liabilities and Special funds + Accruals and deferred income) 
I2 $=($ Reserves + Long-term liabilities + Current liabilities and Special funds + Accruals and deferred income)/Assets

I3 = Interest to be paid/(Profit (loss) on business + Interest to be paid)

$\mathrm{I} 4=[$ Net profit (loss)/Equity capital] $/[$ (Net profit (loss) + Interest to be paid * (1 - Mandatory charges on the financial result/Gross profit (loss)) )/Assets]

I5 $=$ Short-term receivables $*$ The number of days in the period/Net revenues from sales

I6 = Profit (loss) on sales/Net revenues from sales

$\mathrm{Z}_{\mathrm{DW}}=<0.5$ good financial condition

$\mathrm{Z}_{\mathrm{DW}}>0.5$ bankruptcy [Wędzki 2005].

Scoring model - modified scoring method for assessing banking risks according to $\mathrm{A}$. Holda.

A variant of this method allows determining the place of the studied company in the industry using financial ratios [Hołda 2002], therefore slightly different than discriminatory or logit models it presents the results of the carried-out studies that mostly do not consider the specifics of the industry. The author used 12 financial indicators in the method.

$\mathrm{I} 1=$ Profit from sales/Revenues from the sale of products, goods and materials

I2 $=$ Net profit/Total sales revenues

$\mathrm{I} 3=$ Net profit/Average annual equity

I4= Current assets/Current liabilities

I5 $=($ Current assets - Stocks $) /$ Current liabilities

I6 $=$ Short-term investments/Current liabilities

I7 $=($ Average stocks $* 360) /$ Costs of products, goods and materials sold

I8 $=($ Average Short-term receivables *360)/Revenues from the sale of products, goods and materials

I9=(Average Current liabilities *360)/Revenues from the sale of products, goods and materials

I1 $0=$ Liabilities/Assets

I11 $=$ Constant capital/Fixed assets

I12 $=($ Gross profit + Interest to be paid $) /($ Capital instalments + Interest to be paid $)$

Depending on the number of points, a company can reach one of four places:

- a very low place when it obtains $12-20$ points;

- a standard place when it obtains 21-30 points;

- a good place when it obtains 31-40 points;

- a very good place when it obtains $41-48$ points.

Individual indicators after the calculation refer to the value of indicators for the industry [Hołda 2002].

Next the results of the tests were presented. The results for the last research period were presented in synthetic terms. Based on the results of individual early warning models, the classification of verified methods according to the effectiveness of forecasts is presented. 


\section{Results of empirical research}

The article presents the results of individual early warning models for the last research period.

Based on the results obtained, the classification of individual methods was made, distinguishing the number of correct assessments and errors broken down into 1st and 2 nd degree errors. In the case of a first degree error, it marked the assignment of a healthy company to a group of bankrupts. On the other hand, a second-degree error meant that the bankrupt was classified into a group of companies with a good financial standing [Pociecha 2007]. The classification of methods according to the effectiveness of forecasts is presented in Table 2.

Table 2. Classification of early warning models according to the accuracy of the results obtained for the last year of the study

\begin{tabular}{|l|c|c|c|c|}
\hline \multirow{2}{*}{ Model } & \multirow{2}{*}{$\begin{array}{c}\text { Percentage } \\
\text { of accurate } \\
\text { forecasts }\end{array}$} & $\begin{array}{c}\text { Number of correct } \\
\text { assessments }\end{array}$ & \multicolumn{2}{|c|}{$\begin{array}{c}\text { Number of wrong } \\
\text { assessments }\end{array}$} \\
\cline { 4 - 5 } & & & $\begin{array}{c}\text { 1st degree } \\
\text { error }\end{array}$ & $\begin{array}{c}\text { 2nd degree } \\
\text { error }\end{array}$ \\
\hline Hołdar's scoring model & $76 \%$ & 38 & 4 & 8 \\
\hline $\begin{array}{l}\text { “G” INE PAN model by } \\
\text { Mączyńska and Zawadzki }\end{array}$ & $74 \%$ & 37 & 7 & 6 \\
\hline $\begin{array}{l}\text { The Poznań model } \\
\text { (M. Hamrol) }\end{array}$ & $72 \%$ & 36 & 5 & 9 \\
\hline $\begin{array}{l}\text { The Appenzeller and Szarzec } \\
\text { model }\end{array}$ & $66 \%$ & 33 & 6 & 11 \\
\hline Hołda's Model & $62 \%$ & 31 & 9 & 10 \\
\hline Korol's model & $60 \%$ & 30 & 6 & 14 \\
\hline Gajdka and Stos's model & $56 \%$ & 28 & 10 & 12 \\
\hline Wędzki's model & $54 \%$ & 27 & 14 & 9 \\
\hline
\end{tabular}

Source: own study based on the results obtained.

The results obtained allow for the classification of individual methods. A. Hołda's scoring model was the best diagnosing model. In $76 \%$ of cases he correctly classified the surveyed enterprises. The number of correct diagnoses was 38, while the number of incorrect diagnoses was 12, of which four cases concerned the incorrect assignment of healthy companies to a group of bankrupt (1st degree error). In eight cases the model described the bankruptcy financial situation as correct (2nd degree error). The second model with the highest percentage of correct indications was the "G" INE PAN model. He recorded $74 \%$ of correct diagnoses, 37 correct diagnoses and 13 incorrect ones. The model noted 74\% of correct diagnoses, 37 correct and 13 incorrect diagnoses. Among the bad diagnoses, seven concerned the classification 
of healthy enterprises into the group of bankrupt enterprises, while six bankrupt were classified as healthy enterprises. The third model that obtained the effectiveness of forecasts above $70 \%$ was the Poznan model. In $72 \%$ of cases it correctly assessed the financial situation of the surveyed enterprises with respectively 36 accurate diagnoses, five classifications of healthy enterprises as bankrupt, and qualifying nine bankrupt as healthy enterprises. The next one was the the Appenzeller and Szarzec model with $66 \%$ accurate diagnoses -33 correct indications, 17 incorrect diagnoses, of which six from the 1st grade error group and 11 second grade. The Hołda model was also more effective than $60 \%$ - precisely $62 \%$. It correctly diagnosed 31 companies, and 19 companies were incorrectly assigned. Of these nine cases concerned the classification of healthy companies into the group of bankruptcies, and ten bankruptcies were included in the group of healthy enterprises. The Korol model for 30 entities correctly determined the financial condition - which meant an efficiency of $60 \%$. The model incorrectly diagnosed 20 companies. The first degree error was six cases, the second was 14 . The last two models in the classification are: the model of Gajdka and Stos $-56 \%$ of correct diagnoses, and the model of Wędzki - 54\% of correct diagnoses. The effectiveness of the Gajdka and Stos model is 28 correct indications and 22 errors (ten of the first type and 12 of the second). Wędzki's model consists of 27 correctly rated companies and 23 incorrectly qualified enterprises (14 healthy enterprises classified as bankrupt and nine bankrupt diagnosed as healthy).

According to the effectiveness of forecasts, the scoring model was the highest percentage. Then three discriminant models and two logit models were noted. Next, the classification included a discriminant model and a logit model. Analysing the effectiveness of the early warning models, the best diagnoses came from the scoring model. The discrimination models came the second in this respect. These models were to a small extent characterized by a lower prognostic effectiveness than the scoring model. However, the effectiveness of the logit models based on the conducted study can be assessed as the least reliable.

\section{Conclusion}

Analysing the prognostic reliability of early warning models, it can be concluded that all models subject to verification were more than $50 \%$ accurate. The presented discriminant, logit and scoring models, which are included in early warning models, are often characterized by a discrepancy of results. This is certainly reflected in the selection of indicators that individual models use. The scoring model of Hołda achieved the best result from the analysed models. The discrimination models ranked second in terms of effectiveness of diagnosis in most cases proved to be a more reliable tool than the logit models.

The results confirmed the usefulness of early warning models. They allow the analysis and assessment of a company's financial situation in a reliable manner. 
They can also be a useful tool in the restructuring process. The discussed models also allow the rationalization and optimization of business management. They increase the level of control over the financial processes taking place inside the organization. It should also be said that these models should be used as one of many tools, and not the only ones. Diversification of the range of methods will allow for an objective grasp of the differences in the results of individual methods and will contribute to a comprehensive assessment of a company. This will also allow for a possible deepening of the analysis of results giving different diagnoses. This type of approach will allow to obtain optimal results, allowing for the effective management of an organization's finances.

\section{Bibliography}

Antonowicz P., 2010, Zastosowanie macierzy klasyfikacji przedsiębiorstw do oceny zdolności predykcyjnych 52 modeli z-score, Zeszyty Naukowe Politechniki Rzeszowskiej, issue 272/1, Zarządzanie i Marketing, no. 17.

Appenzeller D., Szarzec K., 2004, Prognozowanie zagrożenia upadłościa polskich spółek publicznych, Rynek Terminowy, issue 1.

Balina R., 2012, Skuteczność wybranych modeli dyskryminacyjnych na przykładzie branży robót budowlanych, [in:] Czas na pieniądz. Zarządzanie finansami. Upowszechnienie i transfer wyników badań, D. Zarzecki (ed.), Zeszyty Naukowe Uniwersytetu Szczecińskiego, no. 689, Finanse, Rynki Finansowe, Ubezpieczenia no. 50, Wydawnictwo Uniwersytetu Szczecińskiego, Szczecin.

Czapiewski L., 2009, Efektywność wybranych modeli dyskryminacyjnych w przewidywaniu trudności finansowych polskich spółek giełdowych, [in:] Zarządzanie finansami - teoria i praktyka B. Bernaś (ed.), Prace Naukowe Uniwersytetu Ekonomicznego we Wrocławiu, no. 48.

Czarny A., 2009, System wczesnego ostrzegania dla przedsiębiorstw przemystu spożywczego, [in:] Zarzadzanie finansami firm - teoria i praktyka, B. Bernaś (ed.), Prace Naukowe Uniwersytetu Ekonomicznego we Wrocławiu, no. 48.

Gołębiowski G., Pląsek A., 2018, Skuteczność wybranych modeli dyskryminacyjnych na przyktadzie branży turystycznej, Studia i prace. Kolegium Zarządzania i Finansów, no. 164.

Gołębiowski G., Żywno K., 2008, Weryfikacja skuteczności modeli dyskryminacyjnych na przykładzie wybranych spółek giełdowych, Współczesna Ekonomia, no. 7.

Grzegorzewska E., Runowski H., 2008, Zdolności prognostyczne polskich modeli dyskryminacyjnych w badaniu kondycji finansowej przedsiębiorstw rolniczych, Roczniki Nauk Rolniczych, seria G, vol. 95 , issue $3 / 4$.

Hamrol M., Chodakowski J., 2008, Prognozowanie zagrożenia finansowego przedsiębiorstwa. Wartość predykcyjna polskich modeli analizy dyskryminacyjnej, Badania Operacyjne i Decyzje.

Hołda A., 2001, Prognozowanie bankructwa jednostki w warunkach gospodarki polskiej z wykorzystaniem funkcji dyskryminacyjnej, Rachunkowość, no. 5.

Hołda A., 2002, Ustalanie sytuacji finansowej jednostki z wykorzystaniem mierników syntetycznych - koncepcja wartości średnich, Monitor Rachunkowości i Finansów, no. 1. Kierunki ewolucji sprawozdawczości i rewizji finansowej, B. Micherda (ed.), Warszawa.

Juszczyk S., Pochopień J., Balina R., 2013, Skuteczność polskich modeli do prognozowania bankructwa przedsiębiorstw transportu drogowego towarów masowych, Logistyka, no. 2.

Kisielińska J., 2016, Skuteczność modeli upadtości przedsiębiorstw, Studia Ekonomiczne i Regionalne, vol. 9 , no. 1. 
Kisielińska J., Waszkowski A., 2010, Polskie modele do prognozowania bankructwa przedsiębiorstw i ich weryfikacja, Zeszyty Naukowe Szkoły Głównej Gospodarstwa Wiejskiego w Warszawie, Ekonomika i Organizacja Gospodarki Żywnościowej, no. 82.

Kitowski J., 2011, Próba oceny wiarygodności diagnostycznej bankowych metod badania kondycji finansowej przedsiębiorstw, Prace Naukowe Uniwersytetu Ekonomicznego we Wrocławiu, no. 172.

Koralun-Bereźnicka J., 2006, Ocena możliwości wykorzystania wybranych funkcji dyskryminacyjnych $w$ analizie polskich spółek giełdowych, Studia i Prace Kolegium Zarządzania i Finansów, no. 69.

Korol T., 2010, Systemy wczesnego ostrzegania przedsiębiorstw przed ryzykiem upadłości, Oficyna Wydawnicza Wolters Kluwer, Warszawa.

Kuciński A., 2011, Wykorzystanie wielowymiarowych modeli dyskryminacyjnych do oceny kondycji finansowej przedsiębiorstw na przykładzie wybranych spółek notowanych na rynku NewConnect, Studia i Materiały Polskiego Stowarzyszenia Zarzadzania Wiedzą, no. 41.

Lichota W., 2017, Weryfikacja skuteczności diagnostycznej wybranych modeli analizy dyskryminacyjnej na przykładzie próby przedsiębiorstw z województwa podkarpackiego, Prace Naukowe Uniwersytetu Ekonomicznego we Wrocławiu, no. 472.

Mączyńska E., Zawadzki M., 2006, Dyskryminacyjne modele predykcji upadtości przedsiębiorstw, Ekonomista, no. 2.

Pociecha J., 2007, Problemy prognozowania bankructwa firmy metodą analizy dyskryminacyjnej, Acta Universitatis Lodziensis Folia Oeconomica, no. 205, Łódź.

Rogowski W., 1997, Możliwości wczesnego rozpoznawania symptomów zagrożenia zdolności płatniczej przedsiębiorstwa, Bank i Kredyt, no. 6.

Stasiewski T., 1996, Z-Score-indeks przewidywania upadku przedsiębiorstwa, Rachunkowość, no. 12. Wędzki D., 2005, Zastosowanie logitowego modelu upadłości przedsiębiorstw, Ekonomista, no. 5.

Wojnar J., 2014, Ocena skuteczności modeli analizy dyskryminacyjnej do prognozowania zagrożenia finansowego spólek giełdowych, Zeszyty Naukowe Małopolskiej Wyższej Szkoły Ekonomicznej w Tarnowie, Tarnów.

Zarzecki D., 2003, Analiza dyskryminacyjna jako metoda oceny zagrożenia bankructwem, [in:] Czas na pieniądz. Zarządzanie finansami. Mierzenie wyników i ocena przedsiębiorstw, vol. 1, Wydawnictwo Uniwersytetu Szczecińskiego, Szczecin. 